\title{
Study on Okamoto Kanoko's Novel Creation
}

\author{
Lei $\mathrm{Xu}$ \\ Dalian Neusoft University of Information \\ Dalian, China
}

\begin{abstract}
Under the influence of the Oriental culture of Mahayana Buddhism and the Western civilization which pursues the equality of men and women, Kambenga has created many different feminine images in the novel. The female identity, age and experience of the works are different, but they are also the new women who have strong vitality and break the shackles of traditional values. But in Japanese society under the patriarchal rule, they are also women who have lived a miserable life. Through the analysis of the female image in Kambenga's novels, this paper explores the essence of Okamoto's novel creation, and interprets the unique vitality and feminine consciousness of Okamoto literature.
\end{abstract}

Keywords—okamoto kanoko; woman; vitality; sadness

\section{INTRODUCTION}

Okamoto Kanoko (1889-1939) was a female writer in the early Japanese Showa period. Before becoming a novelist, Kaneko has playing independently in short songs and Buddhist studies. From the beginning of the novel to the death of a sudden haemorrhage in a short span of three years, Kaneko created a large number of other people marvel of popular works, and was praised as Miyamoto Lily, Linfeme son, like the "Three outstanding female writers of the same age" [1]

The research on Kambenga has been based on the author's image of the so-called "Kaneko myth" for a long time. There are Kawabata, Lin Fangxiong and other nearpraise-like rewards, but also has the board Yuan $\mathrm{Zhi} \mathrm{Zi}$, Wenzi and so on the writer himself and the work of the character assimilation negative critique. Husband Gombon, son Gambon and other writers of the same time to the world to describe the Kaneko complicated experience and full of personality legendary life. The husband Gombon even Kaneko called "the Goddess of the spring", "Guanyin Bodhisattva" and "daughter of Life". On the basis of "Kaneko myth", the tortoise well wins Ichiro that Kaneko portray female image is "covet Young Monster", "River Goblin", is "Goddess", "original Mother", "monster" and other real life unreal image. This has brought great influence to Kaneko's literary research, and has almost become the keynote of Okamoto literature for a long time. In recent years, with the development of women's liberation and equality of men and women, more and more scholars, including lacquer field and generation, long JWT and Gonnechun, began to pay close attention to Kambenga's literary works, and made a new interpretation and interpretation of their works from the angles of equality of men and women and female consciousness.
It can be said that Kaneko's novels mainly focus on women, and the description of women is ubiquitous, but today, the analysis of female images in Kambenga novels is rare. "The strength of Flowers" and "the old prostitute copy" is the masterpiece of Kambenga, but in the previous study, these two works are often interpreted as "breeding men's novels, sucking young man vitality of the novel, strong vitality and play the small vitality of the novel" [2], the analysis of the heroine Guizi and the old prostitute is often influenced by the author's image. This paper will analyze the female images in Kaneko's novels by means of textual analysis, and take "The strength of Flowers" and "the old prostitute copy" as an example, to explore the essence of Okamoto's novel creation and the unique feminine view and life view embodied in his works.

\section{OKAMOTO KANOKO}

Kambenga was born in Tokyo Akasaka Castle Peak south-cho home, the family is the Japanese Kanagawa-ken two son of Lake more than more than 300 years of history of the Great Landlord, the Shogunate era of the Queen merchant. Kaneko was aged by his two-year-old brother-the impact of the great snow (Friends Tanizaki Ichiro and others co-founded the second "New Trend" magazine, but unfortunately died prematurely.) early contact with the literary creation.

1906 (Meiji 39) years, Kaneko from and Sheno son, began a short song creation, and in the "star" magazine published a number of works, short song creation to obtain recognition. 1910 (Meiji 43) years, and Gombon married after joining the women's literature magazine "Green Tread", published his first and album-"かろきねたみ". Also have a strong personality of the Kaneko and a flat in less than a year after marriage faced a marital crisis, during this period Kaneko also suffered a succession of literary enlightenment mentor-brother Snow and mother Love death, and the family bankruptcy of the heavy blow, the spirit of collapse. At this time Gombon see his wife's despair heartache, determined to repent, and began to fully support the Kaneko literary creation. In order to solve the marital crisis, the two men began the Buddhist study, Kaneko wrote a large number of articles related to Buddhism, and made significant progress in the study of Buddhism. 1929 (Showa 4) year Kambenga with Gombon for the military Shrink conference materials from far to Europe, after three years of travel life began to emerge in the novel, active in the literary world. 
1936 (Showa 11), at Kawabata's recommendation, Kambenga published her novel debut in the Journal of the Japanese Literature June, "The crane was ill" and boarded the Japanese literary world. This novel, which is based on the mustard Ryunosuke, has aroused widespread repercussions in the Japanese literary circles. Subsequently, Kaneko also published the "Chaos is not divided", "Mother-child" and other works, and gradually consolidate its status in the literary world. 1938 (Showa 13) year December, Kambenga sudden cerebral hemorrhage, and the next February died, only 50 years old. For Kaneko, the real fiction creation was only three years before his death, during this period, Kaneko published a large number of works, including "The strength of Flowers", "Goldfish blinds", "old prostitutes copy" and other masterpieces, such as masterpiece, can be said that Kambenga is a short novel creation time, but the production of female writers.

\section{OKAMOTO KANOKO'S NOVEL CREATION}

In the Kambenga of literary circles as a singer, the classical upbringing does not need to be said, and the fanatical study of religion has also made its extraordinary artistic features, which is particularly evident in his novels. Under the influence of the Oriental culture of Mahayana Buddhism and the Western civilization which pursues the equal right of men and women, Kaneko has formed his own unique and deep understanding of life, and penetrated it into his works, and created many different female images. "The strength of Flowers" in the GUI Zi and "old prostitute copy" in the old prostitute is a representative of the female.

"The strength of Flowers" is Kambenga 1937 (Showa 12) published in the "Literary Spring and Autumn" (15th volume 6th) of the short story. The protagonist Guizi is a woman who pours life into the art of flower arranging, defying any difficulties. She is financially assisting her former lover, a gentle, melancholy male painter. Gui Zi's fanatical pursuit of ideals and vigorous vitality to the male painter brought a heavy burden, so he finally chose a very ordinary life of the girl Guizi. Kaneko, who wrote in the Reading section of the novel, "I will shape the flowers that grow in a weak environment into something as strong as steel." A woman engaged in flower arranging this seemingly weak occupation, but the construction and management of a strong life, and a man holding the primary branch of art, but gradually depressed the demise of 3 . It can be said that Kambenga in the "Flower of the strength" in the world that the weak symbol of the "flower" and "woman" molded into a "strong, tough" image. The heroine is also a representative woman who embodies the Kaneko of male and female equality. Kambenga, a researcher in the novel, has commented on the strength of flowers: "Gui Zi's image is a bold attempt by feminism [4]". In the early days of the Showa Japan in the literary works to portray such a constant pursuit of ideals, the ultimate realization of self-worth of women is not easy, it can be said that "the strength of flowers" in the embodiment of feminism and women's consciousness has a pivotal role.

"Old prostitute Copy" is Kambenga 1938 (Showa 13) year November published in the "Central verdict" works. Mistress Park a young man who aspired to become an inventor of teak, and the youth received the material assistance to the home, in order to ensure that they can indulge in the invention of their favorite work, but in the situation of food and clothing, the youth gradually lost the desire to create inventions, and the vitality of the old prostitutes are more prosperous and bright day by day. "Old prostitute copy" is Kaneko many works of the most highprofile masterpiece. Works published by the community from all walks of life acclaim, even before the Kaneko works did not have a high evaluation of the turtle well wins a Lang said that "This is the Meiji, the history of a handful of famous short story works [5]." "The work of the Ministry was given a high degree of evaluation." Old prostitute copy" has been regarded as the peak of Kambenga novel creation, the study of this work is also quite prevalent. At the same time, this is Kaneko personal more satisfied with the work. After the completion of the creation, Kaneko once said to a flat: "There is no problem, Dad also rest assured that [6]." "The growing old prostitute, the vitality is more and more prosperous, she through her own efforts to gain freedom and longing for a healthy and passionate life." Such an old prostitute image can be said to have overturned the image of the Geisha people, is a new image of the female Kambenga shape.

The female image of Kambenga in the dreary life is inseparable from the background of her time. Women in the Showa era have to make sacrifices in pursuit of ideals and freedom. This is also born in the Meiji period of Kaneko to women's freedom of awareness and critical awareness. People in the process of growth will also have a variety of sacrifices, Kaneko has experienced the unfortunate marital life, the family's bankruptcy, the death of their families and other pain, these also become Kaneko to shape the tragic female image of one of the reasons, and in the work of delicate expression. To make the reader feel the characteristics and reality of that era.

\section{THE CHARACTERISTICS OF OKAMOTO KANOKO'S NOVEL CREATION}

\section{A. Breaking the Traditional Female}

Japan's Showa era of women, generally are no occupation, no economic ability, subject to male parents under the rule of patriarchal system, dependent on male life. However, the women in Kaneko's writings are not such ordinary women, nor are they the mother and wife in the eyes of the world. They have professional, financially independent, and even financial assistance compared to their younger male counterparts. It can be said that the women in Kambenga's novels are the new women who break the tradition.

\section{B. A Woman of Strong Vitality}

"Kaneko literature is summed up in one sentence, which can be said to be ' literature of life ' and a literary work with vitality of 12." As the Japanese literary critic Guyusha said, Kambenga's novels embody the collision and contest between the vitality. The women in their novels have strong and vigorous vitality, while men are weak in vitality, and 
under the influence of vigorous vitality of women gradually dispirited. "The strength of the flowers" in the GUI Zi and "old prostitute copy" in the old prostitute is such a strong vitality of women, two strong vitality of the men were supported by the enormous pressure and a strong burden.

\section{A Woman Who Has Lived a Miserable Life}

The female image of Kambenga is not only a new woman who breaks the traditional and vigorous vitality, but also a woman who has lived a dreary life. Desolation is the age of the Showa period when the father of the era of women's common. Kaneko's female image has broken the traditional innovation, but also inseparable from the common nature of that era.

The female image of Kambenga in the dreary life is inseparable from the background of her time. Women in the Showa era have to make sacrifices in pursuit of ideals and freedom. This is also born in the Meiji period of Kaneko to women's freedom of awareness and critical awareness. People in the process of growth will also have a variety of sacrifices, Kaneko has experienced the unfortunate marital life, the family's bankruptcy, the death of their families and other pain, these also become Kaneko to shape the tragic female image of one of the reasons, and in the work of delicate expression. To make the reader feel the characteristics and reality of that era.

\section{CONCLUSION}

In the Japanese literary world, Kambenga's novel Creation time is short, but it is a female writer with complicated and legendary life experience. She used her life to show the world infinite feelings and incredible, while fully interpreting the value of life as a woman. In Kaneko's novel creation, the description of women is ubiquitous. From the perspective of female emancipation and equality between men and women, the author of the Kambenga and the old prostitute in the "Jin Hua" and "the old prostitute copy" of the women's image, these women are often the pursuit of female beauty, healthy and positive new women. They are not dependent on men's wives and mothers, is a professional and ideal, economic independence, break the tradition of women, is not to succumb to persecution and threats, life is full of longing, than the male vitality of women, is the world cannot understand the lonely women, but also in the patriarchal order under the rule of the miserable life of women. The shaping of these images is inseparable from the personal experience of Kaneko, especially the idea of Oriental Buddhism in Kaneko research and the male-female equality thought of the Western Europe during the European Study tour, which has a great influence on the shaping of the female image. This oriental upbringing and the seamless of Western civilization, Kambenga formed a fusion of eastern and Western culture of the unique creative style.

\section{REFERENCES}

[1] Nishioka min Fukumura. The journey to the son of Okamoto-the literature and religion. Great Falun, 1962、29 (12) : 54-57.
[2] Katsuichiro Kamei. Commentary Lo Extract. Tokyo: Shinchosha, 1940

[3] Saida, Kazuyo. Read "chaotic". Modern literature Japan Women read. Tokyo: Shin-Sundays Company, 1992:87-120.

[4] Kanoko Okamoto. Self-womb-affirmation. Literary, 1938,3(8):86-92.

[5] Satoshi Hisashi. The research note of the child of Okamoto. Tokyo: Jing Persimmon Temple, 1993. 8.

[6] Ippei Okamoto. A record of Kanoko. Tokyo: Shogakukan, 1942. 